IS GROUP AFFILIATION PROFITABLE IN DEVELOPED COUNTRIES?

NOT IN BELGIUM (*)

This version: June 2005

\author{
An BUYSSCHAERT \\ Vrije Universiteit Brussel \\ MICE Department \\ Pleinlaan 2 \\ B - 1050 Brussel \\ Belgium \\ Tel: (0032) 26292118 \\ Fax: (0032) 26292060 \\ e-mail: An.Buysschaert@vub.ac.be
}

\author{
Marc DELOOF \\ University of Antwerp \\ Department of Accounting and Finance \\ Prinsstraat 13 \\ B - 2000 Antwerp \\ Belgium \\ Tel: (0032) 32204169 \\ Fax: (0032) 32204064 \\ e-mail: Marc.Deloof@ua.ac.be \\ Marc JEGERS \\ Vrije Universiteit Brussel \\ MICE Department \\ Pleinlaan 2 \\ B - 1050 Brussel \\ Belgium \\ Tel: (0032) 26292113 \\ Fax: (0032) 26292060 \\ e-mail: Marc.Jegers@vub.ac.be
}

(*) We are grateful to Rez Kabir and participants at the 2004 EIASM Workshop on Corporate Goverance for valuable comments. The usual disclaimer applies. 


\title{
Is Group Affiliation Profitable in Developed Countries? Not in Belgium
}

\begin{abstract}
Several studies find that business groups create value for affiliated companies in developing countries, which are characterized by weak institutions and poorly functioning markets. In these countries, business groups can act as an intermediary between imperfect markets and individual entrepreneurs. This raises the question whether business groups also create value in countries with strong institutions and well-functioning markets, as there are also substantial costs associated with business groups. We investigate the performance of group-affiliated companies in Belgium, and find that these companies significantly underperform compared to stand-alone companies. Moreover, our results suggest that internal capital markets in Belgian business groups result in misallocation of capital.
\end{abstract}

Keywords: business groups, company performance, developed countries, internal capital markets 


\section{INTRODUCTION}

In recent years, a growing literature has investigated the role of diversified business groups. This literature primarily focuses on emerging countries, which are often characterized by weak institutions and poorly functioning capital, labor and product markets. Disclosure is often inadequate, and corporate governance, law and law enforcement are generally weak. In this context, intermediaries such as investment banks, mutual funds and venture capitalists are not fully evolved, and large diversified business groups can create value by acting as an intermediary between imperfect markets and individual entrepreneurs. They internally replicate the functions which in advanced economies are provided by external intermediary institutions.

Studies on emerging markets generally reveal that group affiliation is indeed associated with a better performance [e.g. Chang and Choi, 1988, Chang and Hong, 2000, for Korea; Gonenc, Kan and Karadagli, 2004, for Turkey; Keister, 1998, for China; Khanna and Palepu, 1999, 2000a, 2000b, for Chile and India; Khanna and Rivkin, 2001, for an international sample]. This raises the question whether business groups can also create value for companies in developed countries with strong institutions and well-functioning capital, labor and product markets. In these countries, the potential benefits of business groups are likely to be significantly lower than in emerging markets.

Moreover, there are substantial costs associated with business groups. First, it has been shown that internal capital markets may lead to misallocation of capital in multidivisional structures, by strong subsidiaries subsidising weaker divisions (e.g. Lamont, 1997; Rajan, Servaes and Zingales, 2000; Scharfstein and Stein, 2000; Shin and Stulz, 1998). Second, business groups 
are often characterized by a high disparity between control rights and ownership rights of the controlling shareholder, which may lead to greater agency costs. The disparity between control rights and ownership rights may induce the controlling shareholder to divert resources out of companies, at the expense of minority shareholders (a phenomenon referred to as ‘tunneling’ by Johnson, La Porta, Lopes-de-Silanes and Shleifer, 2000). Holmén and Högfeldt (2005) argue that in countries with strong institutions, where tunneling is less likely, the separation of ownership and control through pyramidal structures can lead to significant overinvestment by group members. Their empirical investigation of Swedish business groups confirms this hypothesis. A number of studies on the performance of Japanese Keiretsu affiliates find that Keiretsu affiliation lowers performance, which suggests that the costs of Keiretsu affiliation are greater than the benefits (e.g. Caves and Uekusa, 1976; Dewenter et al., 2001; Nakatani, 1984; Prowse, 1992). Some studies find that even in developing countries group affiliation may reduce company value and profitability (e.g. Claessens, Fan and Lang, 2002; George, Kabir and Douma, 2004; Joh, 2003).

In this paper, we investigate the performance of stand-alone companies and companies which are affiliated with listed holding companies in Belgium. As in many other European countries, financial and industrial groupings and combines play an important role in the accumulation and allocation of capital in the Belgian economy. Large numbers of companies, which are often active in a wide range of industries, are linked by networks of share ownership and interlocking directorates and are controlled by holding companies through intermediate layers of subholding companies. This technique allows holding companies to control a pyramid of companies without having to participate directly in the equity of all daughter companies. 
We find that over the five-year period 1997-2001 group-affiliated companies significantly underperform compared to stand-alone Belgian companies, which suggests that in Belgium group affiliation destroys value. Moreover, we find a negative relationship between net intragroup financing and the performance of affiliated companies, which indicates that internal capital markets in Belgian business groups result in misallocation of capital, by transferring funds from good performers to poorly performing group companies. Our study is, to the best of our knowledge, the first to investigate how affiliation with a business group affects company performance in a Continental European country.

This paper is organized as follows. First, we discuss holding companies and business groups in Belgium, and develop some hypotheses on the value of group affiliation and internal capital markets. Next, we present the data and the methods used in this paper, and report the empirical results. These results lead us to consider why inefficient business groups would be able to endure. We draw some conclusions in the last section.

\section{HOLDING COMPANIES AND BUSINESS GROUPS IN BELGIUM}

In Belgium and in other Continental European countries, business groups often consist of layers of quoted and non-quoted holding companies, in which the ultimate shareholders control non-holding companies through complex cross-holdings and pyramidal structures. A holding company can be defined as "a professionally managed institution owning a portfolio of stocks in public and private companies with the purpose of influencing them. In realizing this objective, a holding company acts both as a financial intermediary and as an active shareholder.” (Banerjee, Leleux and Vermaelen, 1997). An typical example of a Belgian business group is the holding company group around business man Albert Frère. Figure 1 
presents a simplified version of the shareholder structure of this group in 1998. The group is dominated by the Frère-Bourgeois company, which is a non-listed entity directly controled by Albert Frère. A chain of intermediate holding companies (Nationale Portefeuillemaatschappij (NPM), Groep Brussel Lambert (GBL), Electrafina) allows him to control a vast industrial empire with relatively small cash flow stakes.

Insert Figure 1 about here

The importance of Belgian business groups, based on holding company structures, should be seen in its historical context. As a reaction to the worldwide financial crisis at the beginning of the 1930s, in 1934 a law was adapted that forced the universal banks, which historically dominated the Belgian economy, to separate their banking and investment activities. This led to the establishing of holding companies, which owned a diversified portfolio of investments in a wide range of industrial and commercial activities, and were the largest shareholders in Belgium throughout the $20^{\text {th }}$ century. Pyramidal ownership structures allowed these holding companies to maintain control over their subsidiaries with only limited investments. In recent times, Belgian holding companies remain important investors in financial, industrial and commercial companies (Becht, Chapelle and Renneboog, 2000).

Because of fundamental differences in managerial organization, comparisons of groups controlled by Belgian holding companies with American conglomerates are bound to be misleading. American conglomerates are tightly structured, whereas Belgian groups are mostly loose organizations with an ill-defined corporate policy. Belgian corporate groups also differ from Japanese financial Keiretsu groups. While Belgian groups have a hierarchical 
structure, with a holding company controlling a pyramid of companies, members of the Japanese Keiretsu are considered equals. Traditionally, these members have close ties with one bank, which plays an important role in the financing of these companies, and is responsible for monitoring the business affairs. For Belgian groups, it is the controlling holding company that monitors members and intervenes in corporate policy or replaces management when deemed necessary. Banks stick to traditional banking activities and therefore play a smaller role in the management and financing of group members than does the main bank in a Keiretsu. Furthermore, while there is extensive co-ordination of trade through a group trading company in the Japanese Keiretsu, no trading companies or centralized buying or selling agents exist in Belgian groups, which are primarily financial.

The separation of ownership and control in pyramidal structures generates a strong incentive for the controlling shareholders to divert resources between companies in the group. However, there is no proof of expropriation of minority shareholders in Belgian business groups (see Buysschaert, Deloof and Jegers, 2004). Nevertheless, the shares of listed Belgian holding companies generally trade at a significant discount to their estimated net asset value, which might be caused by the extraction of private benefits by the controlling shareholders (Rommens, Deloof and Jegers, 2004). Interestingly, Holmén and Högfeldt (2005), who observe a similar discount for holding companies in Swedish pyramidal groups, find evidence that in Sweden this discount is not caused by extraction of private benefits, but by overinvestment of group companies.

Belgian business groups were created at times when institutions in Belgium were weak and external capital markets were poorly developed. Nowadays, Belgium is a country with strong institutions and well-developed external capital markets, which are fully integrated in the 
international capital markets. It can therefore be expected that group affiliation will bring few benefits for modern Belgian companies. As there are substantial costs associated with business group affiliation, we expect that these outweigh the benefits, reducing the profitability of Belgian companies affiliated to a group. We therefore predict that companies belonging to a business group will have lower profitability than stand-alone companies, ceteris paribus. This leads to the following hypothesis:

Hypothesis 1. Group-affiliated companies have a lower profitability than stand-alone companies.

Many business groups have an internal capital market where group members can (re)finance in the form of e.g. debt, guarantees or receivables. Deloof (1998) finds that in the 1987-1991 period Belgian group-affiliated companies faced less financing constraints than stand-alone companies, consistent with the hypothesis that internal capital markets redistribute funds among group members. An internal capital market may create value through its advantages over external capital markets, as it may contain superior information about investment opportunities (Myers and Majluf, 1984), and it can provide efficient monitoring (Jensen and Meckling, 1976). However, there is a dark side to internal capital markets, as they may lead to cross-subsidization of poorly performing business units by good performers (e.g. Lamont, 1997; Rajan, Servaes and Zingales, 2000; Scharfstein and Stein, 2000; Shin and Stulz, 1998). Lincoln, Gerlach and Ahmadjian (1996) and Gedajlovic and Shapiro (2002) find evidence on cross-subsidization in Japanese Keiretsu groups, while the results of Chang and Hong (2000) and Ferris, Kim and Kitsabunnarat (2003) suggest cross-subsidization in Korean Chaebol groups. 
If the internal capital market allows financially constrained group members to fund good investment opportunities, it will create value. In this case, we expect a positive relation between receiving financial resources and profitability of group members. On the other hand, if resources are allocated to poorly performing group members, there will be a negative relation between receiving financial resources and profitability of group members.

If companies have access to efficient and liquid external capital markets, as is the case in Belgium, they should not need an internal capital market to fund valuable investments. We therefore expect that receiving intragroup financing will not be associated with higher profitability, as good investment projects can generally be funded externally anyway. This leads to the following hypothesis:

Hypothesis 2. Group-affiliated companies that receive financial resources from the group do not have a higher profitability than group-affiliated companies not receiving financial resources from the group.

If internal capital markets lead to cross-subsidization of poor performers, we even expect a negative relation between group financing and profitability. It should be noted that this negative relation does not necessarily imply an inefficient redistribution of funds. Indeed, it can be argued that the support of a financially troubled group member will pay for itself in the long run, after its successful rescue and turnaround (see e.g. Chang and Hong, 2000). However, this would imply that group affiliation creates value, as inefficient bankruptcy of group companies is avoided. So, if we find that on average group affiliation lowers profitability and there is a negative relation between group financing and profitability, this would suggest that there is inefficient allocation of capital in Belgian business groups. 


\section{DATA AND SAMPLE}

Our sample consists of Belgian group companies and stand-alone companies. We define group companies as those companies which are affiliated with holding companies, listed on the Brussels Stock Exchange (BXS) in 2001. We used the classification of the BXS, which was in use until February 2000, to identify listed holding companies. The BXS defined holding companies as "those companies whose purpose is to invest in other (quoted) companies, except financial institutions”. To this list of holding companies, we added one holding company which went public after February 2000 (Almancora). Mutual funds and state-owned holding companies were excluded. As a result, we obtained a list of 25 listed Belgian holding companies. As some of these holding companies belong to the same group, they represent 20 business groups.

In Belgium, all companies have to deposit their annual reports at the National Bank of Belgium. For each of the selected holding companies, we consulted the 2001 consolidated annual report, and included all Belgian subsidiaries which were fully or proportionally consolidated. According to the Belgian accounting law, all subsidiaries which are directly or indirectly controlled by the parent company should be consolidated. If one of these subsidiaries had a consolidated annual report itself, its Belgian subsidiaries were also incorporated in the sample. Financial companies and companies for which only an abbreviated annual report was available were not included (small companies are allowed to deposit only an abbreviated annual report at the National Bank). To identify stand-alone Belgian companies, we first selected “independent" companies from the Belfirst-DVD of Bureau Van Dijk. Bureau Van Dijk defines independent companies as “any company with 
known recorded shareholders, none of which having more than $24.9 \%$ of direct or total ownership”. From the resulting list we excluded financial companies, and companies for which only an abbreviated annual report was available. We also excluded all companies that reported group liabilities, group receivables or group guarantees. The purpose of this last restriction was to remove companies that are misclassified as independent by Bureau Van Dijk.

Accounting data were available for each of these companies for the period 1997-2001. We only included company-years which fulfilled the following criteria concerning the accounting data: (1) the company has a "normal" legal status in year t, (2) the age of the company is at least one in year t, and (3) sales and total assets are positive in year t and t-1.

A matched sample of group companies and stand-alone companies was constructed, based on three digit NACE-BEL industry code and Sales. The Belgian NACE-BEL industry classification is very similar to the US-SIC industry classification. Our final sample includes 188 group companies for which 673 company-years are available, and 188 stand-alone companies for which 742 company-years are available ${ }^{1}$. These are mostly private companies: only 8 group companies and 1 stand-alone company were listed.

\section{METHODS}

\section{Variable measurement}

Performance measures. We use the return on assets as a measure of company performance. Return on assets avoids distortions in the measurement of profitability due to the 
firms' fincancing decisions, and captures profitability of the firm as a whole. As most companies in our sample are not publicly traded, we cannot use stock market based profitability measures. Joh (2003) argues that accounting profitability is likely to be a better performance measure than stock market based measures because (a) stock prices are less likely to reflect all available information when the stock market shows inefficiency, (b) a company's accounting profitability is more directly related to its financial viability than is its stock market value, and (c) accounting measures allow to evaluate the performance of privately held companies as well as that of publicly traded companies. The Return on Assets in year $\mathrm{t}$ is defined as earnings before interest and taxes in year $\mathrm{t}$, divided by total assets at the beginning of year $\mathrm{t}$.

Group measures. To distinguish between affiliated companies and stand-alone companies, we use a dummy variable Group Affiliation, which is one for companies affiliated with a group, and zero for other companies. There may be significant differences in the size of the holding groups considered in our study. Larger groups might be more beneficial, as they e.g. may have easier access to resources, can allocate these resources more efficiently or can reduce cost through economies of scale, and have a positive influence on the performance of its members (George, Kabir and Douma, 2004). We therefore also consider the variable Group Size, which is the logarithm of consolidated total assets of the group.

The impact of intragroup financing on company performance will be analyzed by including variables on intragroup borrowing and lending. We investigate the impact of (a) Group Receivables, which are long-term and short-term receivables from the group at the beginning of year t, divided by total assets at the beginning of year t; (b) Group Liabilities, which are long-term and short-term liabilities to the group at the beginning of year $\mathrm{t}$, divided by total 
assets at the beginning of year t; (c) Received Group Guarantees, which are the guarantees given or irrevocably promised by the group as security for debts or commitments of the company at the beginning of year t, divided by total assets at the beginning of year $t$; and (d) Given Group Guarantees, which are guarantees given or promised by the company itself to support other group companies at the beginning of year t, divided by total assets at the beginning of year t. The information on these variables can be found in the notes of Belgian financial statements.

We measure the net borrowing/lending position of a company towards the group to which it belongs by the variable Net Group Financing, which is defined as Group Liabilities plus Received Group Guarantees minus Group Receivables minus Given Group Guarantees. If Net Group Financing is positive, this means the company is a net borrower from the group; if it is negative, the company is a net lender to the group. Because of insufficient information, we are not able to take into account intragroup trade and intragroup financing through investments in equity.

Control variables. In our model, we also include a set of variables to capture company specific characteristics that may influence company performance: company size, company age, leverage, company growth and industry. Company size is measured as the logarithm of total assets at the beginning of the year. Larger companies may benefit from economies of scale and may be less financially constrained. Our measure of company age is the number of years since the company was established. Older, more stable and mature companies are expected to have lower profitability. Leverage is measured as total debt to total assets, both at the beginning of the year. On the one hand, debt may yield a disciplinary effect when free cash flows exist, as a rise in debt increases default risk (Jensen, 1986). Companies can reduce 
wasteful investment and increase performance to secure their survival. On the other hand, a higher leverage may increase conflicts of interest between equity holders and creditors. In highly leveraged companies, the equity holders with limited liability may encourage the company to take excessive risks (Stiglitz and Weiss, 1981). Our company growth measure is sales growth, defined as the logarithm of the ratio of the current to previous year's sales. High growth companies are expected to be more profitable. We also include industry dummies in the model to capture possible industry effects. However, the coefficient estimates for these industry dummies will not be reported. Variable definitions are summarized in Table I.

Insert Table I about here

Table II provides descriptive statistics for the full sample (panel A), and for group companies and stand-alone companies separately (panel B). The average return on assets is a meager 2.43\% (panel A). It is slightly higher for stand-alone companies (2.61\%) than for group companies (2.23\%) but the difference is not statistically significant. The average sales growth is also low at 0.03 , and is different between group companies and stand-alone companies. For the group companies, net group financing is on average +0.04 , which implies that the group companies are on average net borrowers from the group.

Insert Table IIA and IIB about here 


\section{Regression analysis}

In our sample, there is variation in both the cross-section and time dimensions. One might be tempted to pool the data and estimate a fixed-effects model to exploit all the variation in our panel data set. However, fixed-effects estimation is not possible, since "Group Affiliation", which is the central variable in our study, is itself a fixed effect. A Hausmann test rejected the use of a Variance Components model. Chirinko and Elston (2003) study long-run differences between German companies with and without bank affiliation, and reject fixed effects estimation for two reasons. First, since group affiliated influence changes little over time, this influence can only be identified in the cross-section. Second, using the available time variation requires specification of the temporal dynamics of the financial variables. However, while these dynamics may be interesting on their own, they can produce misleading estimates for the parameter of interest in this study. Pesaran and Smith (1995) find that for dynamic models, pooling and aggregating give inconsistent and potentially highly misleading estimates of the coefficients when the coefficients differ across groups. This is true even if the model is correctly specified, although a cross-section can provide consistent estimates of the long-run effects that are robust for misspecification of the dynamics in the underlying micro model. Thus, these arguments suggest a cross-sectional analysis of the sample. We will therefore rely on OLS on means estimation, where the data are averaged along the time dimension. We have estimated all the regressions reported in the paper also with plain OLS, but this leads to very similar results (not reported).

To test hypothesis 1 , we regress return on assets (ROA) on control dummy group affiliation (GA), and the control variables size, age, leverage, sales growth and industry dummies. 
(1) $\mathrm{ROA}_{\mathrm{t}}=\mathrm{C}+\beta_{1} \mathrm{GA}_{\mathrm{t}}+\beta_{2}$ (control variables)

In the other regressions, we add interaction variables to capture group specific information. A first indicator is the impact of group size in interaction with group affiliation (2). In regression (3) to (5), we explore the influence of intragroup financing (hypothesis 2). We interact group affiliation with net group financing (regression (3)). In regression (4), we investigate whether the effect of net group financing depends on whether net group financing is positive or negative, by including an additional interaction variable where we restrict net group financing to be positive (4). Finally, we regress return on assets on the interaction of group affiliation with each single component of net group financing (regression (5)).

(2) $\quad \mathrm{ROA}_{\mathrm{t}}=\mathrm{C}+\beta_{1} \mathrm{GA}_{\mathrm{t}}+\beta_{2}\left(\mathrm{GA}_{\mathrm{t}} \mathrm{x}\right.$ group size $)+\beta_{3}$ (control variables)

(3) $\quad \mathrm{ROA}_{\mathrm{t}}=\mathrm{C}+\beta_{1} \mathrm{GA}_{\mathrm{t}}+\beta_{2}\left(\mathrm{GA}_{\mathrm{t}} \mathrm{x}\right.$ Net Group Financing $\left.\mathrm{t}\right)+\beta_{3}$ (control variables)

(4) $\mathrm{ROA}_{\mathrm{t}}=\mathrm{C}+\beta_{1} \mathrm{GA}_{\mathrm{t}}+\beta_{2}\left(\mathrm{GA}_{\mathrm{t}} \mathrm{x}\right.$ Net Group Financing $)$

$+\beta_{3}\left(\mathrm{GA}_{\mathrm{t}} \mathrm{x}\right.$ Net Group Financing $\mathrm{x}($ Net Group Financing $\left.\mathrm{t}>0)\right)$

$+\beta_{4}$ (control variables)

(5) $\mathrm{ROA}_{\mathrm{t}}=\mathrm{C}+\beta_{1} \mathrm{GA}_{\mathrm{t}}+\beta_{2}\left(\mathrm{GA}_{\mathrm{t}} \mathrm{x}\right.$ Group Receivables $)+\beta_{3}\left(\mathrm{GA}_{\mathrm{t}} \mathrm{x}\right.$ Group Liabilities $\left._{\mathrm{t}}\right)+\beta_{4}\left(\mathrm{GA}_{\mathrm{t}} \mathrm{x}\right.$ Received group Guarantees $\left.\mathrm{t}\right)+\beta_{5}\left(\mathrm{GA}_{\mathrm{t}} \mathrm{x}\right.$ Given group guarantees $\left.\mathrm{t}_{\mathrm{t}}\right)+\beta_{6}($ control variables $)$ 


\section{EMPIRICAL RESULTS}

Table III presents the regression results. Company specific control variables are significant, with the exception of age. Company size and sales growth have a significant positive coefficient, indicating that larger companies, who may be less financing constrained and may benefit from economies of scale, and companies with growth potential are more profitable. Highly leveraged companies also have lower profitability.

Insert Table III about here

In regression (1), we investigate whether group companies affiliated are more profitable than stand-alone companies. The results show a negative coefficient for the group affiliation dummy, statistically significant at the $1 \%$ level. This implies that companies affiliated with a Belgian holding company underperform in regard to stand-alone companies, and suggests that group affiliation destroys company value. This is in contrast to the results of some studies on business groups in emerging markets like India or Chile, but is consistent with results of studies on Japanese Keiretsu. Our results thus indicate that in a developed country like Belgium, the beneficial effects of the presence of business groups and their goals may be questioned.

In the second regression, an interaction variable of group affiliation and group size is added. This interaction coefficient is significantly negative at the $1 \%$ level, while the coefficient of group affiliation becomes significantly positive at the $10 \%$ level $(p=0.08)$. This suggests that specifically large business groups in Belgium destroy value for affiliated companies. 
In regressions (3) to (5), we investigate the relation between profitability and intragroup financing. When we include the interaction variable [group affiliation $\mathrm{x}$ net group financing], this variable is significantly negative at the $1 \%$ level. This implies that a net inflow of intragroup financing is associated with lower profitability, and a net outflow of intragroup financing is associated with higher profitability. In regression (4) an extra interaction variable is included which incorporates the restriction that net group financing must be positive. This additional variable is not significant, which suggests that the relation between net group financing and profitability does not depend on net group financing being positive or negative. The more funds a company gets from the group, the lower its profitability, and the more funds a company transfers to the group, the more profitable it is. So it seems that through the internal capital market, funds are transferred from good performing to poorly performing companies in the group. A similar result is found by George, Kabir and Douma (2004) for Indian business groups. They observe a lower performance for group companies compared to stand-alone companies, and their results indicate that this underperformance is caused by inefficient profit redistribution.

In the last regression, we interact group affiliation with each component of net group financing separately. Both interactions with intragroup receivables and intragroup liabilities are significant at the $1 \%$ level: there is a positive relation between intragroup receivables and performance, and a negative relation between intragroup liabilities and performance. Intragroup guarantees show no significance. These results again confirm that transferring money to the group is associated with higher profitability and receiving money from the group with lower profitability. 
As a robustness check, we also estimated the regressions reported in this paper for a larger, unmatched sample which includes all stand-alone companies. The regressions (3), (4) and (5), which include intragroup financing variables, were also estimated for a limited sample which includes only group companies. The results of all these regressions (not reported) are similar to the ones reported in the paper, with one notable exception: the group size coefficient is not statistically significant if we include all stand-alone companies in the sample.

\section{HOW CAN INEFFICIENT BUSINESS GROUPS ENDURE?}

If Belgian business groups destroy value, this raises the question why they still exist. One would expect that an organizational form which is not adapted to the modern world disappears. Some authors propose cultural arguments, which relate value and belief systems to organizational form, to explain the continuing existence of business groups (e.g. Chung, 2001). Collin (1998), who studies Swedish business groups, argues that these groups may have accumulated sufficient resources during the period of their succes, making them capable of surviving quite independent of their present economic (in)efficiency. As such business groups may be considered institutional "left-overs".

Some recent studies provide a political explanation for the endurance of business groups in developed countries. According to Collin (1998) and Högfeldt (2004), Swedish groups are supported by the government because they possess a governance capacity that the government can make use of. Morck, Wolfenzohn and Yeung (2004) point out that in many countries, business groups are owned by a limited number of wealthy families. Groups allow this elite to control a large part of the corporate sector. This has also been the case in Belgium through the 20th century. In an underdeveloped financial system, business groups give the elite privileged 
access to finance. However, it can be expected that financial development destroys this competitive advantage. Indeed, better disclosure rules and enforcement in a developed financial market reduces the relative importance of the collateral and reputation of the business elite, while permitting newcomers to enter and compete away profits. The business elite will therefore have strong incentives to lobby politicians for policies that hinder institutional development of capital markets, erect a variety of entry barriers, and preserve the status quo. Political influence might also be instrumental to owner's private benefits of control. Rajan and Zingales (2003) point out that many countries that currently have small stock markets had large and dynamic stock markets a century ago. Belgium is a typical example. They propose that in these countries, a first generation of corporate insiders raise money from public investors, gain control of most of the corporate sector, and then later lobby for policies that cause financial market atrophy.

Consistent with the political influence hypothesis, Van Zundert (2005) finds that through the $20^{\text {th }}$ century, most major Belgian companies had significant political connections. He investigates the extent to which (former) members of parliament and (former) cabinet ministers were a director of the most important listed companies for five years of the $20^{\text {th }}$ century $(1912,1929,1955,1971$, and 2000), and finds that more than half of the companies in his sample had at least one "political” director. Moreover, most holding companies and financial institutions, which are the key members of Belgian business groups, had "political” directors, who often were former cabinet ministers. 


\section{CONCLUSION}

In this study, we analyzed the performance of companies affiliated to Belgian holding groups, as compared to the performance of stand-alone companies. Our results show that group companies in Belgium underperform compared to stand-alone companies. This suggests that holding groups do not create value for their member companies. Moreover, we find a negative relationship between net intragroup financing and the performance of affiliated companies, which suggests that internal capital markets in Belgian business groups result in misallocation of capital, by transferring funds from good performers to poorly performing group companies.

Our results are not surprising, as they confirm those of similar studies on Japanese keiretsu groups and Indian business groups. In an environment with strong institutions and welldeveloped markets, the potential benefits of business groups are unlikely to outweigh the costs. An intriguing question is why inefficient business groups are able to survive. There may be a cultural preference for business groups, business groups may live on resources accumulated in the past, and the may rely on political support. It is clear that further research is needed on this point.

\section{REFERENCES}

Banerjee, S., Leleux, B. and Vermaelen, T. (1997). 'Large shareholdings and corporate control: an analysis of stake purchases by French holding companies'. European Financial Management, 3, 23-44. 
Becht, M., Chapelle, A. and Renneboog, L. (2000). 'Shareholding cascades: the separation of ownership and control in Belgium’. In F. Barca and M. Becht, Who controls corporate Europe. Oxford University Press.

Berger, P.G. and Ofek, E. (1995). 'Diversification's effect on firm value'. Journal of Financial Economics, 37, 39-65.

Buysschaert A., Deloof, M. and Jegers, M. (2004). 'Equity sales in Belgian corporate groups: expropriation of minority shareholders? A clinical study’. Journal of Corporate Finance, 10, 81-103.

Caves , R. and Uekusa, M. (1976). Industrial organisation in Japan. Washington, DC: Brookings Institute.

Chang, S.J. and Choi, U. (1988). 'Strategy, structure and performance of Korean business groups: a transactions cost approach’. Journal of Industrial Economics, 37, 141-158.

Chang, S.J. and Hong, J. (2000). 'Economic performance of group-affiliated companies in Korea: intragroup resource sharing and internal business transactions'. Academy of Management Journal, 43, 429-448.

Chirinko, R.S. and Elston, J.A. (2003). 'Finance, control and profitability: the influence of German banks’. CESifo Working Paper Series, 1073.

Chung, C.-H. (2001). 'Markets, culture and institutions: the emergence of large business groups in Taiwan, 1950s-1970s’. Journal of Management Studies, 38, 719-745.

Claessens, S., Fan, J.P.H. and Lang, L.H.P. (2002). 'The benefits and costs of group affiliation: evidence from East Asia’. Working Paper, University of Amsterdam. 
Collin, S.-O. (1998). 'Why are these islands of conscious power found in the ocean of ownership? Institutional and governance hypotheses explaining the existence of business groups in Sweden', Journal of Management Studies, 35, 719-746.

Deloof, M. (1998). 'Internal capital markets, bank borrowing, and financing constraints: evidence from Belgian firms’. Journal of Business Finance and Accounting, 25, 945-968.

Dewenter, K., Novaes, W., and Pettway, R.H. (2001). 'Visibility versus complexity in business groups: evidence from Japanese Keiretsu’. Journal of Business, 74, 79-100.

Ferris, S.P., Kim, K.A., and Kitsabunnarat, P. (2003). 'The costs (and benefits?) of diversified business groups: the case of Korean Chaebols’. Journal of Banking and Finance, 27, 251273.

Gedajlovi, E. and Shapiro, D.M. (2002). 'Ownership structure and firm profitability'. Academy of Management Journal, 45, 565-575.

George, R., Kabir, R. and Douma, S. (2004). 'Business groups and profit redistribution: a boon or bane for firms?'. Working Paper, Tilburg University and Technical University Eindhoven.

Gonenc, H., Kan, O.B. and Karadagli, E.C. (2004). 'Corporate diversification and internal capital markets: evidence from Turkisch business groups'. Working Paper, Hacette University, Western Connecticut State University, and Cankaya University.

Högfeldt, P. (2004). ‘The history and politics of corporate ownership in Sweden’. Working Paper, National Bureau for Economic Research.

Holmén, M. and Högfeldt, P. (2005). 'Pyramidal discounts: tunneling or agency costs?'. Working Paper, European Corporate Governance Institute. 
Jensen, M.C. (1986). 'Agency costs of free cash flow, corporate finance and takeovers'. American Economic Review, 76, 323-329.

Jensen, M.C. and Meckling, W.H. (1976). 'Theory of the firm: managerial behavior, agency costs, and ownership structure'. Journal of Financial Economics, 3, 305-360.

Joh, S.W. (2003). 'Corporate governance and firm performance: evidence from Korea before the economic crisis'. Journal of Financial Economics, 68, 287-322.

Johnson, S., La Porta, R., Lopez-de-Silanes, F. and Shleifer, A. (2000). 'Tunneling'. American Economic Review, 90, 22-27.

Keister, L. (1998). 'Engineering growth: business group structure and firm performance in China’s transition economy’. American Journal of Sociology, 10, 404-440.

Khanna, T. and Palepu, K. (1999). 'Policy shocks, market intermediation, and corporate strategy: the evolution of business groups in Chile and India'. Journal of Economics and Management Strategy, 8, 271-310.

Khanna, T. and Palepu, K. (2000a). 'Is group affiliation profitable in emerging markets? An analysis of diversified Indian business groups’. Journal of Finance, 55, 867-891.

Khanna, T. and Palepu, K. (2000b). The future of business groups in emerging markets: longrun evidence from Chile. Academy of Management Journal, 43, 268-285.

Khanna, T. and Rivkin, J. (2001). 'Estimating the performance effects of networks in emerging markets’. Strategic Management Journal, 22, 45-74.

Lamont, O.A. (1997). 'Cash flow and investment: evidence from internal capital markets'. Journal of Finance, 52, 83-109. 
Lewellen, W.G. (1971). 'A pure financial rational for the conglomerate merger'. Journal of Finance, 26, 521-537.

Lincoln, J., Gerlach, M., and Ahmadjian, C. (1996). 'Keiretsu network and corporate performance in Japan’. Americal Journal of Sociology, 61, 67-88.

Morck, R., D. Wolfenzohn, B. Yeung (2004), Corporate governance, economic entrenchment and growth, Working Paper, National Bureau of Economic Research.

Myers, S.C. and Majluf, N. (1984). 'Corporate financing and investment decisions when firms have information about that investors do not have'. Journal of Financial Economics, 13, 187-221.

Nakatani, I. (1984). 'The economic role of financial corporate grouping'. In M. Aoki (Ed.), The economic analysis of the Japanese firm, 227-258. Amsterdam: North-Holland.

Pesaran, M.H. and Smith, R. (1995). 'Estimating long-run relationships from dynamic heterogeneous panels'. Journal of Econometrics, 68, 79-113.

Prowse, S. D. (1992). 'The structure of corporate ownership in Japan'. Journal of Finance, 47, 1121-1140.

Rajan, R., Servaes, H. and Zingales, L. (2000). 'The cost of diversity: diversification discount and inefficient investment'. Journal of Finance, 55, 35-80.

Rajan, R.G. and Zingales L. (2003), 'The great reversals: the politics of financial development in the twentieth century', Journal of Financial Economics, 69, 5-50.

Rommens, A., Deloof, M. and Jegers, M. (2004). Why do holding companies trade at a discount? Working Paper, University of Antwerp. 
Scharfstein, D.S. and Stein, J.C. (2000). 'The dark side of internal capital markets: divisional rent-seeking and inefficient investment’. Journal of Finance, 55, 2537-2564.

Shin, H.H. and Stulz, R.M. (1998). 'Are internal capital markets efficient?'. Quarterly Journal of Economics, 108, 531-552.

Stiglitz, J. and Weiss, A. (1981). 'Credit rationing in markets with imperfect information'. American Economic Review, 71, 393-410.

Van Zundert (2005). 'De waarde van politieke connecties voor ondernemingen' (the value of political connections for companies). Unpublished Manuscript, University of Antwerp.

Weinstein, D. E. and Yafeh, Y. (1998). 'On the Costs of a Bank-Centered Financial System: Evidence from the Changing Main Bank Relations in Japan'. Journal of Finance, 53, 635-672. 


\section{NOTES}

${ }^{1}$ For all company-years, group affiliation and independence is based on information for 2001 because there is insufficient information available to determine affiliation and independence for the other years. 
FIGURES AND TABLES

\section{FIGURE 1}

Simplified version of the shareholder structure of Albert Frère's pyramidal empire in 1998.

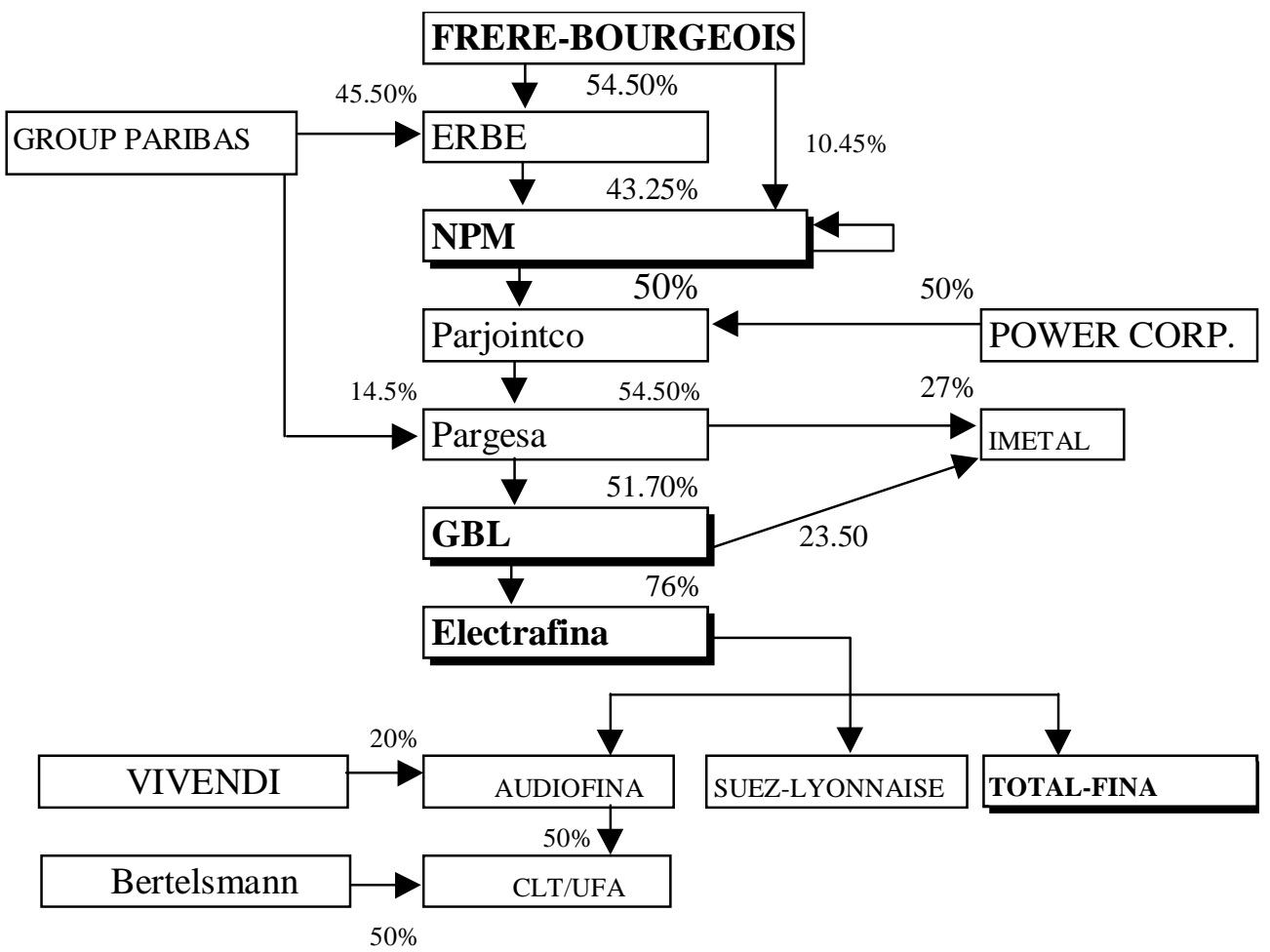

Source : Annual report Nationale Portefeuille Maatschappij, 1998

Note: Bold face names refer to holding companies within the group structure 
TABLE I

Variable definitions

\begin{tabular}{|c|c|}
\hline \multicolumn{2}{|l|}{ Dependent variable } \\
\hline Return on Assets & EBIT / total assets (expressed as a percentage) \\
\hline \multicolumn{2}{|l|}{ Independent variables } \\
\hline Company size & Log(total assets ) \\
\hline Age & Company age \\
\hline Leverage & Total debt / total assets \\
\hline Sales growth & Log(sales $t_{t} /$ sales $\left._{t-1}\right)$ \\
\hline Industry & $\begin{array}{l}\text { Industry dummies } \\
\text { (based on } 1 \text { digit NACE-BEL industry code) }\end{array}$ \\
\hline Group affiliation & $\begin{array}{l}\text { Dummy; } 1 \text { if the company is affiliated with a listed Belgian } \\
\text { holding company, } 0 \text { if the company is a stand-alone company }\end{array}$ \\
\hline Group size & Log(consolidated total assets of the group) \\
\hline Group receivables & Receivables from group / total assets \\
\hline Group liabilities & Liabilities to group / total assets \\
\hline Received group guarantees & Guarantees received from group / total assets \\
\hline Given group guarantees & Guarantees given to the group / total assets \\
\hline Net group financing & $\begin{array}{l}{[(\text { Group liabilities }+ \text { received group guarantees) - (group }} \\
\text { receivables + given group guarantees) }] \text { / total assets }\end{array}$ \\
\hline
\end{tabular}


TABLE IIA

Descriptive statistics and correlation matrix (376 companies, 1997-2001)

\begin{tabular}{l|lll|llllll}
\hline Variable & Mean & Median & S.d. & $(1)$ & (2) & (3) & (4) & (5) & (6) \\
\hline (1) Return on assets & 2.43 & 2.28 & 6.08 & 1.00 & & & & & \\
(2) Group affiliation & 0.48 & 0.50 & 0.27 & -0.03 & 1.00 & & & & \\
(3) Company size & 3.89 & 3.80 & 0.70 & 0.05 & 0.24 & 1.00 & & & \\
(4) Age & 22.37 & 15.00 & 20.71 & 0.01 & -0.15 & 0.24 & 1.00 & & \\
(5) Leverage & 0.62 & 0.68 & 0.29 & -0.12 & -0.10 & -0.04 & -0.15 & 1.00 & \\
(6) Sales growth & 0.03 & 0.02 & 0.27 & 0.06 & 0.02 & 0.01 & -0.03 & 0.03 & 1.00 \\
\hline
\end{tabular}


TABLE IIB

Descriptive statistics (376 companies, 1997-2001)

\begin{tabular}{l|lll|llc}
\hline & \multicolumn{3}{|c|}{ Group companies } & \multicolumn{3}{c}{ Stand-alone companies } \\
\hline Variable & Mean & Median & S.d. & Mean & Median & S.d. \\
\hline Return on assets & 2.23 & 2.36 & 7.39 & 2.61 & 2.26 & 4.56 \\
Company size & 4.06 & 4.02 & 0.83 & 3.73 & 3.72 & 0.51 \\
Age & 19.18 & 12.00 & 19.48 & 25.25 & 19.00 & 21.37 \\
Leverage & 0.59 & 0.64 & 0.31 & 0.65 & 0.72 & 0.26 \\
Sales growth & 0.03 & 0.02 & 0.33 & 0.03 & 0.02 & 0.19 \\
Group size & 14.59 & 13.76 & 2.63 & & & \\
Net group financing & 0.04 & 0.00 & 0.46 & & & \\
Group receivables & 0.15 & 0.04 & 0.23 & & & \\
Group liabilities & 0.16 & 0.03 & 0.25 & & & \\
Received group guarantees & 0.05 & 0.00 & 0.31 & & & \\
Given group guarantees & 0.02 & 0.00 & 0.08 & & & \\
\hline
\end{tabular}


TABLE III:

Determinants of Return on Assets (OLS on means, 376 companies, 1997-2001)

\begin{tabular}{|c|c|c|c|c|c|}
\hline Variable & (1) & (2) & (3) & (4) & (5) \\
\hline Constant & $\begin{array}{l}2.76^{*} \\
(0.03)\end{array}$ & $\begin{array}{l}2.93^{*} \\
(0.02)\end{array}$ & $\begin{array}{l}2.70^{*} \\
(0.03)\end{array}$ & $\begin{array}{l}2.69^{*} \\
(0.03)\end{array}$ & $\begin{array}{l}2.38^{\dagger} \\
(0.06)\end{array}$ \\
\hline Group affiliation (GA) & $\begin{array}{l}-0.91^{* *} \\
(0.01)\end{array}$ & $\begin{array}{c}2.53^{\dagger} \\
(0.08)\end{array}$ & $\begin{array}{l}-0.69^{\dagger} \\
(0.06)\end{array}$ & $\begin{array}{l}-0.68^{\dagger} \\
(0.09)\end{array}$ & $\begin{array}{l}-0.47 \\
(0.26)\end{array}$ \\
\hline GA $x$ group size & & $\begin{array}{l}-0.24^{* *} \\
(0.02)\end{array}$ & & & \\
\hline GA $x$ net group financing & & & $\begin{array}{c}-2.42^{* * *} \\
(0.00)\end{array}$ & $\begin{array}{c}-2.47^{* * *} \\
(0.00)\end{array}$ & \\
\hline $\begin{array}{l}\text { GA } x \text { net group financing } x \text { (net } \\
\text { group financing }>0 \text { ) }\end{array}$ & & & & $\begin{array}{c}0.19 \\
(0.90)\end{array}$ & \\
\hline GA x group receivables & & & & & $\begin{array}{c}3.39^{* * *} \\
(0.00)\end{array}$ \\
\hline GA x given group guarantees & & & & & $\begin{array}{l}3.14 \\
(0.27)\end{array}$ \\
\hline GA $x$ group liabilities & & & & & $\begin{array}{c}-5.08^{* * *} \\
(0.00)\end{array}$ \\
\hline GA x received group guarantees & & & & & $\begin{array}{l}-0.35 \\
(0.67)\end{array}$ \\
\hline Company size & $\begin{array}{l}0.63^{*} \\
(0.02)\end{array}$ & $\begin{array}{l}0.65^{*} \\
(0.02)\end{array}$ & $\begin{array}{l}0.48^{\dagger} \\
(0.07)\end{array}$ & $\begin{array}{c}0.48^{\dagger} \\
(0.07)\end{array}$ & $\begin{array}{c}0.90^{\dagger} \\
(0.08)\end{array}$ \\
\hline Age & $\begin{array}{l}-0.01 \\
(0.52)\end{array}$ & $\begin{array}{l}-0.01 \\
(0.45)\end{array}$ & $\begin{array}{l}-0.01 \\
(0.63)\end{array}$ & $\begin{array}{l}-0.01 \\
(0.63)\end{array}$ & $\begin{array}{l}-0.01 \\
(0.78)\end{array}$ \\
\hline Leverage & $\begin{array}{l}-2.81^{* * *} \\
(0.00)\end{array}$ & $\begin{array}{l}-2.86^{* * *} \\
(0.00)\end{array}$ & $\begin{array}{c}-1.89^{* * *} \\
(0.00)\end{array}$ & $\begin{array}{c}-1.89^{* * *} \\
(0.00)\end{array}$ & $\begin{array}{l}-1.21^{\dagger} \\
(0.07)\end{array}$ \\
\hline Sales Growth & $\begin{array}{c}1.23^{\dagger} \\
(0.07)\end{array}$ & $\begin{array}{c}1.23^{\dagger} \\
(0.07)\end{array}$ & $\begin{array}{c}1.29^{\dagger} \\
(0.06)\end{array}$ & $\begin{array}{c}1.29^{\dagger} \\
(0.06)\end{array}$ & $\begin{array}{c}1.21^{\dagger} \\
(0.08)\end{array}$ \\
\hline Industry dummies & Included & Included & Included & Included & Included \\
\hline $\mathrm{R}^{2}$ & 0.03 & 0.04 & 0.05 & 0.05 & 0.05 \\
\hline F-test & $3.91^{* *}$ & $4.15^{* *}$ & $5.09^{* * *}$ & $4.73^{* * *}$ & $5.05^{* * *}$ \\
\hline
\end{tabular}

$p$-values, based on heteroscedasticity-consistent standard errors in parentheses.

$\dagger p<.10$

$* p<.05$

$* * p<.01$

$* * * p<.001$ 